Article

\title{
In Situ Ternary Boride: Effects on Densification Process and Mechanical Properties of WC-Co Composite Coating
}

\author{
Junfeng Bao ${ }^{1,2,3}$, Yueguang $\mathrm{Yu}^{2,3, *}$, Bowen Liu ${ }^{1}$, Chengchang Jia ${ }^{1}$ and Chao $\mathrm{Wu}^{2,3}$ \\ 1 Institute for Advanced Materials and Technology, University of Science and Technology Beijing, \\ Beijing 100083, China; Bao_jf@bgrimm.com (J.B.); lbw_1211@126.com (B.L.); jcc@ustb.edu.cn (C.J.) \\ 2 BGRIMM Technology Group, Beijing 100160, China; 18101380412@163.com \\ 3 Beijing Engineering Technology Research Center of Surface Strengthening and Repairing of Industry Parts, \\ Beijing 102206, China \\ * Correspondence: yuyg@bgrimm.com
}

Received: 5 March 2020; Accepted: 22 April 2020; Published: 24 April 2020

\begin{abstract}
New coatings resistant to corrosion in high-temperature molten zinc aluminum were prepared by supersonic flame spraying of various composite powders. These composite powders were prepared by mixing, granulation, and heat treatment of various proportions of Mo- $\mathrm{B}_{4} \mathrm{C}$ powder and WC and Co powder. X-ray diffraction (XRD), transmission electron microscopy (TEM), scanning electron microscopy (SEM), high-angle annular dark-field scanning transmission electron microscopy (HAADF-STEM), energy dispersive X-ray spectroscopy (EDS), and mechanical analysis were used to study the effects of $\mathrm{Mo}-\mathrm{B}_{4} \mathrm{C}$ on the microstructure, phase, porosity, bonding strength, and elastic modulus of the composite powder and coating. Results show that the addition of an appropriate quantity of $\mathrm{Mo}-\mathrm{B}_{4} \mathrm{C}$ reacts with $\mathrm{Co}$ to form ternary borides $\mathrm{CoMo}_{2} \mathrm{~B}_{2}$ and $\mathrm{CoMoB}$. Ternary boride forms a perfect continuous interface, improving the mechanical properties and corrosion resistance property of the coating. When the amount of $\mathrm{Mo}-\mathrm{B}_{4} \mathrm{C}$ added was $35.2 \%$, the mechanical properties of the prepared coating reached optimal values: minimum porosity of $0.31 \pm 0.15 \%$, coating bonding strength of $77.81 \pm 1.77 \mathrm{MPa}$, nanoindentation hardness of $20.12 \pm 1.85 \mathrm{GPa}$, Young's modulus of $281.52 \pm 30.22 \mathrm{GPa}$, and fracture toughness of $6.38 \pm 0.45 \mathrm{MPa} \cdot \mathrm{m}^{1 / 2}$.
\end{abstract}

Keywords: WC-Co; Mo-B ${ }_{4} \mathrm{C}$; in situ reaction; ternary boride; densification process

\section{Introduction}

Hot-dip galvanizing is a very economical and efficient method to prevent steel corrosion during atmospheric exposure [1]. However, the wear and corrosion of sink rolls and other components during the galvanizing process are major challenges in the galvanizing industry. Each year, the loss caused by component corrosion across the $\sim 57$ hot-dip galvanizing production lines in the United States is nearly 500 million US dollars [2-4]. Moreover, the surface state of the sink rolls directly affects the quality of the galvanized steel surface; hence, avoiding sink roll corrosion is important. The corrosion rate of common alloy and steel products is faster because of the wettability of the metal in molten zinc aluminum. W, Mo, B, side elements, and other elements are not wettable in molten zinc; thus, they can be used as corrosion-resistant sink rolls in hot-dip galvanizing. On the one hand, the plasticity and impact resistance of W-Mo alloys are poor. On the other hand, W-Mo alloys are too expensive for use as sink rolls, limiting their use $[5,6]$. Therefore, typically, a protective coating is applied to prevent the sink rolls from corroding in molten zinc. In recent years, WC-Co, $\mathrm{Al}_{2} \mathrm{O}_{3}, \mathrm{Zr}_{2} \mathrm{O}_{3}-\mathrm{Y}_{2} \mathrm{O}_{3}, \mathrm{MoB}-\mathrm{CoCr}$, and other coatings have been used in sink roll anti-corrosion coatings. According to the different properties of the coatings, they can be roughly divided into cermet coatings, oxide ceramic coatings, and new 
MoB-CoCr coatings. Of these, the cermet coatings, represented by WC-Co, exhibit better corrosion resistance and wear resistance. Simultaneously, owing to the existence of metal binder, the coating has better toughness under the premise of maintaining high hardness [7-10]. Its main anti-corrosion principle is to form an aluminum-rich phase as a protective film to isolate the molten zinc aluminum. However, owing to the high Co metal content, the coating easily yields to metal ternary corrosion, leading to coating damage [11]. $\mathrm{Al}_{2} \mathrm{O}_{3}$ and $\mathrm{Zr}_{2} \mathrm{O}_{3}-\mathrm{Y}_{2} \mathrm{O}_{3}$ have high melting points, making them almost impervious to molten zinc aluminum; they are primarily used as oxide ceramics to prepare anticorrosive coatings via plasma spraying. However, the disadvantage of oxide ceramic coatings is poor toughness [12]. In recent years, a new type of thermal spraying material, $\mathrm{MoB}-\mathrm{CoC}$, has become widely used in molten zinc aluminum corrosion-resistant hot-dip galvanizing [13-15]. The service life of a MoB-CoCr coating is more than $600 \mathrm{~h}$.

Because of the high economic impact of solutions to these problems, scholars have remained committed to the study of the surface coatings of sink rolls used for preparing hot-dip galvanized steels. However, many scholars have studied the characteristics of MoB-CoCr coatings. The durability of MoB-CoCr coatings in the hot-dip galvanizing industry is clearly better than those of other alloys owing to the non-wettability of boride in molten zinc, the compactness of the coating with its consequently lower defect rate, and the superior mechanical properties, all meeting the needs of sink roll use. Boride has gradually substituted WC cermet coatings because of the poor wettability of molten zinc-aluminum, particularly in molten zinc-aluminum with high aluminum content at temperatures up to $600{ }^{\circ} \mathrm{C}[16,17]$.

Boride technology development can be traced through a series of key studies. Sugiyama et al. [18] successfully prepared a WC-WB- $\mathrm{W}_{2} \mathrm{~B}$ composite coating via in-situ synthesis based on $\mathrm{B}_{4} \mathrm{C}-\mathrm{W}-\mathrm{WC}$. Their coating exhibited high density, excellent mechanical properties, and high resistance to molten zinc corrosion because of the high B content of its ceramic phase. In the past two decades, WC-Co coatings have been widely used as sink roll surface protection materials. The corrosion-resistance of these coatings remains mainly limited by their high Co metal content. Wang et al. [19] proposed the use of $\mathrm{Co}_{6} \mathrm{~W}_{6} \mathrm{C}$ and $\mathrm{Co}_{3} \mathrm{~W}_{3} \mathrm{C}$ phases instead of $\mathrm{Co}$ to improve the corrosion resistance of WC-Co. However, this proposal produced an excess of brittle phases, thereby reducing the toughness of the WC-Co coating. Therefore, nano WC powders were instead used for preparation, and good corrosion resistance was achieved. These methods have their own advantages, but the use of nano WC powder increases the cost of the coating for all such methods. In contrast, too high a proportion of the ceramic phase risks losing the toughness of the coating, resulting in a decline in mechanical properties. In the actual production process, boride ceramic coating is commonly used as a corrosion-resistant coating material at $700{ }^{\circ} \mathrm{C}$, under which the steel softens because of the high temperature such that the boride ceramic coating can meet the conditions. The modified WC-Co coating is usually used at $630^{\circ} \mathrm{C}$ to achieve higher toughness.

Herein, a WC-Co coating modified using $\mathrm{Mo}-\mathrm{B}_{4} \mathrm{C}$ was used to prepare corrosion-resistant coatings under working conditions of about $600{ }^{\circ} \mathrm{C}$. The in-situ reaction of Mo- $\mathrm{B}_{4} \mathrm{C}$ and $\mathrm{Co}$ to form a ternary boride binder was investigated, as were the effects of the in-situ reaction on the coating's porosity, interface, and mechanical properties. A low-porosity coating rich in CoMoB and $\mathrm{CoMo}_{2} \mathrm{~B}_{2}$ ternary boride, which could enhance resistance to molten zinc-aluminum corrosion, was successfully prepared with mechanical properties equivalent to those of traditional WC-Co coatings, but stronger resistance to molten zinc-aluminum corrosion due to the ternary boride.

\section{Materials and Methods}

\subsection{Preparation of Composite Powder}

In this experiment, WC powder (average particle size $1.10 \mu \mathrm{m}$; Xiamen Jinlu Special Alloy Co., Ltd., Xiamen, China), Mo powder (average particle size $1.75 \mu \mathrm{m}$; BGRIMM Advanced Material Science \& Technology Co., Ltd., Beijing, China), Co powder (average particle size $1.52 \mu \mathrm{m}$; Zhejiang 
Huayou Cobalt Industry Co., Ltd., Jiaxing, China), and $\mathrm{B}_{4} \mathrm{C}$ powder (average particle size $1.95 \mu \mathrm{m}$; Nanuo Advanced Materials Co., Ltd., Guangzhou, China) were selected as raw material powders. Mixing, granulation, and heat treatment were applied to prepare the composite powder.

Each of the four powders was mixed according to the powder mass ratio shown in Table 1. A planetary ball mill was used for full blending, utilizing $5 \mu \mathrm{m}$ WC grinding balls at a ball:material ratio of 5:2. A $3 \mathrm{wt} . \%$ polyethylene glycol (PEG4000) aqueous solution in deionized water was added as a ball mill additive. The speed was maintained at $80 \mathrm{rad} / \mathrm{min}$ for $24 \mathrm{~h}$.

Table 1. Raw material composition of composite powders (wt. \%).

\begin{tabular}{cccccc}
\hline \multirow{2}{*}{ Sample } & WC & \multicolumn{3}{c}{ Mo, $\mathbf{B}_{\mathbf{4}} \mathbf{C}$} & Co \\
\cline { 3 - 5 } & & $\mathbf{M o}+\mathbf{B}_{\mathbf{4}} \mathbf{C}$ & $\mathbf{M o}$ & $\mathbf{B}_{\mathbf{4}} \mathbf{C}$ & \\
\hline $1 \#$ & 0 & 88.0 & 78.8 & 9.2 & 12.0 \\
$2 \#$ & 17.6 & 70.4 & 63.1 & 7.3 & 12.0 \\
$3 \#$ & 35.2 & 52.8 & 47.3 & 5.5 & 12.0 \\
$4 \#$ & 52.8 & 35.2 & 31.5 & 3.7 & 12.0 \\
$5 \#$ & 70.4 & 17.6 & 15.8 & 1.8 & 12.0 \\
$6 \#$ & 88.0 & 0 & 0 & 0 & 12.0 \\
\hline
\end{tabular}

An LGZ-50 centrifugal spray dryer was used for granulation of the mixed powder slurry. The inlet temperature was $300{ }^{\circ} \mathrm{C}$, the outlet temperature was $120^{\circ} \mathrm{C}$, and the slurry flow rate was $650 \mathrm{~mL} / \mathrm{min}$. Binder removal and heat treatment were performed in a tubular resistance furnace. To avoid other reactions, an argon gas shielding atmosphere was selected for the heat treatment, with a gas flow rate of $1 \mathrm{~L} / \mathrm{min}$. The furnace temperature was increased at a rate of $10^{\circ} \mathrm{C} / \mathrm{min}$ to $180{ }^{\circ} \mathrm{C}$, then $1{ }^{\circ} \mathrm{C} / \mathrm{min}$ to $420^{\circ} \mathrm{C}$, then maintained at $420^{\circ} \mathrm{C}$ for $2 \mathrm{~h}$ to ensure PEG binder removal. To ensure that the heating process would not crack the sample under excessive internal stress, the temperature was increased to $600{ }^{\circ} \mathrm{C}$ at which it was then maintained for $1 \mathrm{~h}$. In the powder reaction stage, the temperature was increased at a rate of $10{ }^{\circ} \mathrm{C} / \mathrm{min}$ to $1000{ }^{\circ} \mathrm{C}$ heat preservation for $0.5 \mathrm{~h}$, then increased at a rate of $5{ }^{\circ} \mathrm{C} / \mathrm{min}$ to $1260^{\circ} \mathrm{C}$ heat preservation and maintained at $1260{ }^{\circ} \mathrm{C}$ for $3 \mathrm{~h}$ to ensure full reaction, followed by furnace cooling. After heat treatment, the powder was ground and sieved with 325 mesh and 800 mesh sieves to obtain a composite powder with a particle size distribution of $18-45 \mathrm{~nm}$.

\subsection{Preparation of Coatings}

The composite powder was used for supersonic flame spraying, with 316L stainless steel used as a matrix. Considering the large difference in thermal expansion rates between the two materials, NiCrAlY alloy was chosen as the intermediate bond layer. The coating was prepared using a JP-8000 supersonic flame sprayer (PROXAIR company, Boston, MA, USA). After cleaning and sandblasting the 316L stainless steel matrix, the NiCrAlY intermediate layer, and the composite coating were successively sprayed. The spraying distance was $360 \mathrm{~mm}$, and the coating thickness was about $250 \mu \mathrm{m}$. The microstructure and mechanical properties of the prepared coating were then further analyzed.

\subsection{Analysis}

The effects on the microstructure, morphology, densification, and mechanical properties of the composite powder and coating of adding Mo- $\mathrm{B}_{4} \mathrm{C}$ were analyzed. A SU 5000 SEM (HITACHI, Tokyo, Japan) was used to observe the microstructure of the raw material, composite powder, and coating. A D8 ADVANCE X-ray diffractometer $(\mathrm{Cu} \mathrm{K} \alpha, \lambda=0.154184 \mathrm{~nm}$; BRUKER, Karlsruhe, Germany), was used to analyze the phase contained in the composite powder at a scanning speed $010 \% \mathrm{~min}$. The microstructure of the coating was analyzed using a JEOL JEM-1010 TEM, whereas the microscopic phase of the coating was analyzed via selected area electron diffraction (SAED). The diffusion forms of elements in each phase were determined using mapping in scanning transmission electron microscopy 
(STEM) mode. The samples observed using transmission electron microscopy were cut using a focused ion beam (FIB).

The epoxy adhesive coating was selected in accordance with ASTM C633-79, and the bonding strength of the coating was tested using a WDW-100A electronic universal testing machine. The porosity of the coating was measured in accordance with ASTM E2109-01. Image J software was used to calculate the porosities of 30 coating tissue photos for each sample. CSM-NHT2 nanometer indentation measurements of loading-unloading were used to measure the elastic modulus of the coating cross section and the nanometer hardness. Testing conditions were as follows: a Berkovich pressure head was used for linear loading, the maximum load was $10 \mathrm{mN}$, the loading and unloading rates were both $20 \mathrm{mN} / \mathrm{min}$, and the pressure was maintained for $5 \mathrm{~s}$ under the maximum load. The fracture toughness $\left(K_{I C}\right)$ of the coating was characterized using the Vickers indentation method, as measured using a 402MVATM Vickers hardness tester. The test parameters were as follows: loading load was $300 \mathrm{~g}$, holding pressure was $10 \mathrm{~s}$. Fracture toughness $\left(K_{I C}\right)$ was evaluated according to the half-diagonal and crack length of the indentation after each indentation. The fracture toughness of the coating was calculated as

$$
K_{\text {IC }}=0.079 \frac{P}{a^{3 / 2}} \log \left(\frac{4.5 a}{c}\right),
$$

where $P$ is the applied load in $\mathrm{N}, a$ is the length in micrometers of the half-diagonal of the indentation, and $c$ is the length in micrometers from the center of the indentation to the end of the crack. The formula applied was $0.6 \leq c / a \leq 4.5$, and for each sample at least 10 points were measured. These samples with different coating were tested for molten zinc aluminum corrosion. The experimental equipment was a RJ-75-6 crucible furnace. The composition of the molten zinc aluminum was Al- $43.5 \% \mathrm{Zn}-1.5 \% \mathrm{Si}$, the experimental temperature was controlled at $630^{\circ} \mathrm{C}$ for $72 \mathrm{~h}$. Then, the microstructure of the coating after $72 \mathrm{~h}$ corrosion of different coatings was analyzed using SEM and EDS.

\section{Results and Discussion}

\subsection{Characterization of the Raw Materials}

The surface morphologies are shown in Figure 1 for the four raw material powders $\mathrm{B}_{4} \mathrm{C}, \mathrm{Co}$, $\mathrm{Mo}$, and WC. The $\mathrm{B}_{4} \mathrm{C}$ particle morphology selected in the experiment was that of an irregular block with edges and corners. Co particles were subspherical or dumbbell-shaped, agglomerating together. Mo particles were larger spherical or subspherical particles, also showing agglomeration. WC particle size was relatively small, with a more irregular shape.
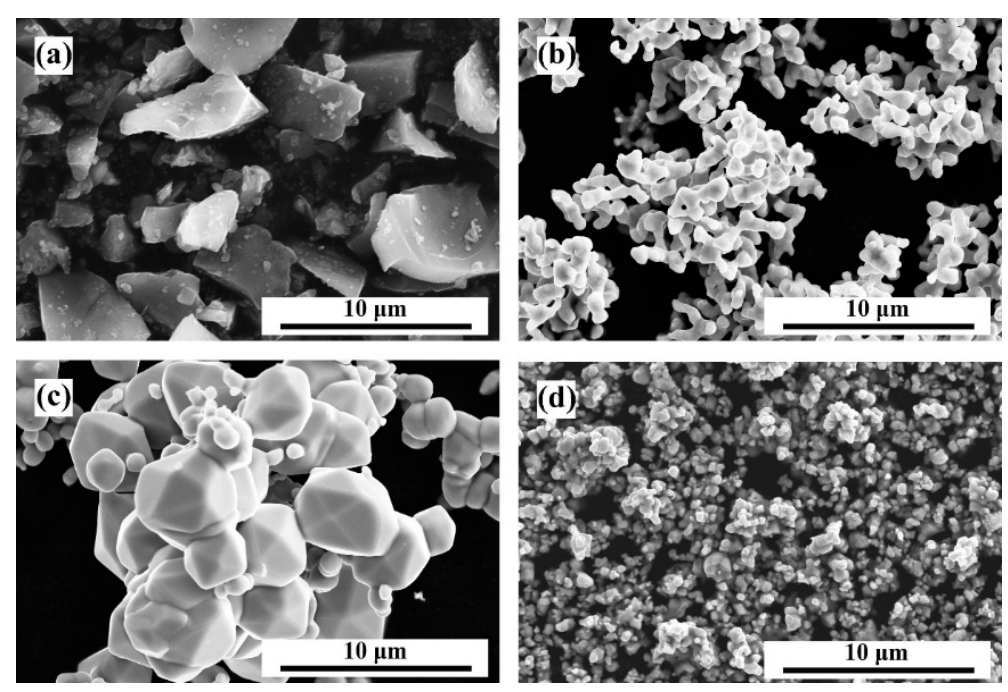

Figure 1. Scanning electron microscopy (SEM) micrographs of raw material powders: $(\mathbf{a}) \mathrm{B}_{4} \mathrm{C}$; (b) Co; (c) Mo; (d) WC. 


\subsection{Characterization of the Prepared Composite Powders}

Powders with different ratios of raw materials were prepared through the process of mixing, granulation, and heat treatment to form composite powders. These were fully mixed to form metallurgical bonds; chemical reactions then produced specific phase compositions. Phase analyses of these composite powders are shown in Figure 2a,b. Sequentially, from sample \#6 through sample \#1, the quantity of $\mathrm{Mo}-\mathrm{B}_{4} \mathrm{C}$ added increased from $0 \mathrm{wt}$. \% to $88 \mathrm{wt}$. \%, dictating the range of phases of the mixed powders post heat treatment. Sample \#6 was a typical WC-12Co cemented carbide powder. Post granulation and heat treatment, WC and Co failed to react to form a new phase; hence, the WC and Co physical phases were retained. The phase compositions of samples \#3 through \#5 were similar. With increasing amount of added $\mathrm{Mo}-\mathrm{B}_{4} \mathrm{C}$, the relative peak strength of Co gradually decreased, whereas the relative peak strength of ternary-boride $\mathrm{CoMoB}$ and $\mathrm{CoMo}_{2} \mathrm{~B}_{2}$ generated by the reaction of $\mathrm{Co}$ with $\mathrm{Mo}-\mathrm{B}_{4} \mathrm{C}$ gradually increased. This pattern indicates that $\mathrm{Co}$ and $\mathrm{Mo}-\mathrm{B}_{4} \mathrm{C}$ consumed the original $\mathrm{Co}$ and produced two ternary borides, $\mathrm{CoMoB}$ and $\mathrm{CoMo}_{2} \mathrm{~B}_{2}$, and that the quantity of these products gradually increased with increasing $\mathrm{Mo}-\mathrm{B}_{4} \mathrm{C}$ addition. Literature survey and XRD results indicate that the reactions occurring during the heat treatment were those shown in Equations (2) and (3) [20].

$$
\begin{gathered}
5 \mathrm{Mo}+\mathrm{B}_{4} \mathrm{C} \rightarrow 4 \mathrm{MoB}+\mathrm{MoC} \\
2 \mathrm{Co}+3 \mathrm{MoB} \rightarrow \mathrm{CoMo} 2 \mathrm{~B} 2+\mathrm{CoMoB}
\end{gathered}
$$

(a)

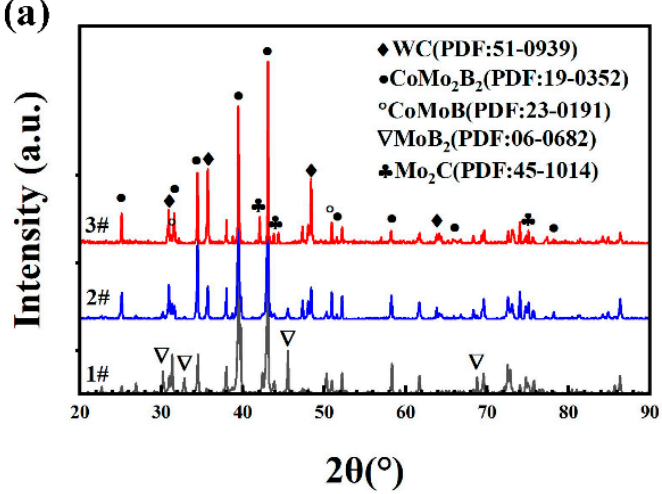

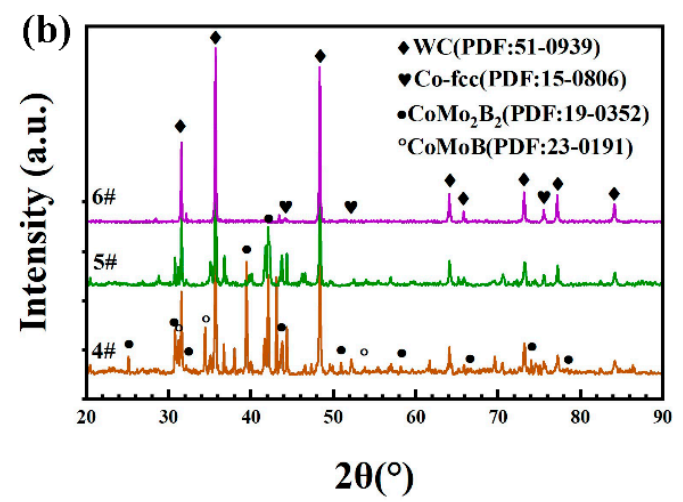

Figure 2. X-ray diffraction $(\mathrm{XRD})$ patterns of composite powders with different raw material compositions: (a) 1\#, 2\#, 3\#; (b) 4\#, 5\#, 6\#.

As Mo participated in the reaction to generate $\mathrm{MoC}$, some of the $\mathrm{MoC}$ was decarburized at high temperature during the heat treatment such that $(\mathrm{Mo}, \mathrm{W})_{2} \mathrm{C}$ was observed in the phase of sample \#3. With increasing addition of $M o-B_{4} C$, the $M_{0} B_{2}$ phase was observed in samples \#1 and \#2, and the relative peak strength of $\mathrm{MoB}_{2}$ increased with increasing addition of $\mathrm{Mo}-\mathrm{B}_{4} \mathrm{C}$. This behavior can be explained by noting that the amount of $\mathrm{Co}$ added was fixed at $12 \%$, whereas the additive amount of Mo- $\mathrm{B}_{4} \mathrm{C}$ was excessive such that part of the Mo reacted with $\mathrm{B}_{4} \mathrm{C}$ to generate $\mathrm{MoB}_{2}$. Notably, the chemical reactions describing the full process of preparing the composite powder were relatively complicated; the reactions in Equations (2) and (3) [20] only represent the main reactions. The presence of free Co was observed even in sample \#1, of which Mo- $\mathrm{B}_{4} \mathrm{C}$ constituted $88 \mathrm{wt}$. \%.

Figure 3 shows the surface morphology and cross-sectional morphology after heat treatment of composite powders comprising different ratios of the same raw materials. The surface morphology shows that owing to the large amount of Mo- $\mathrm{B}_{4} \mathrm{C}$ addition, most of the bonded phase Co and Mo- $\mathrm{B}_{4} \mathrm{C}$ reacted to generate ternary boride $\mathrm{CoMoB}$ and $\mathrm{CoMo}_{2} \mathrm{~B}_{2}$. Moreover, because of excessive addition of $\mathrm{Mo}-\mathrm{B}_{4} \mathrm{C}, \mathrm{MoB}$ or $\mathrm{MoB}_{2}$ was generated. These reactions thus resulted in a large reduction of bonded-phase $\mathrm{Co}$ and generated boride ceramic phases. 

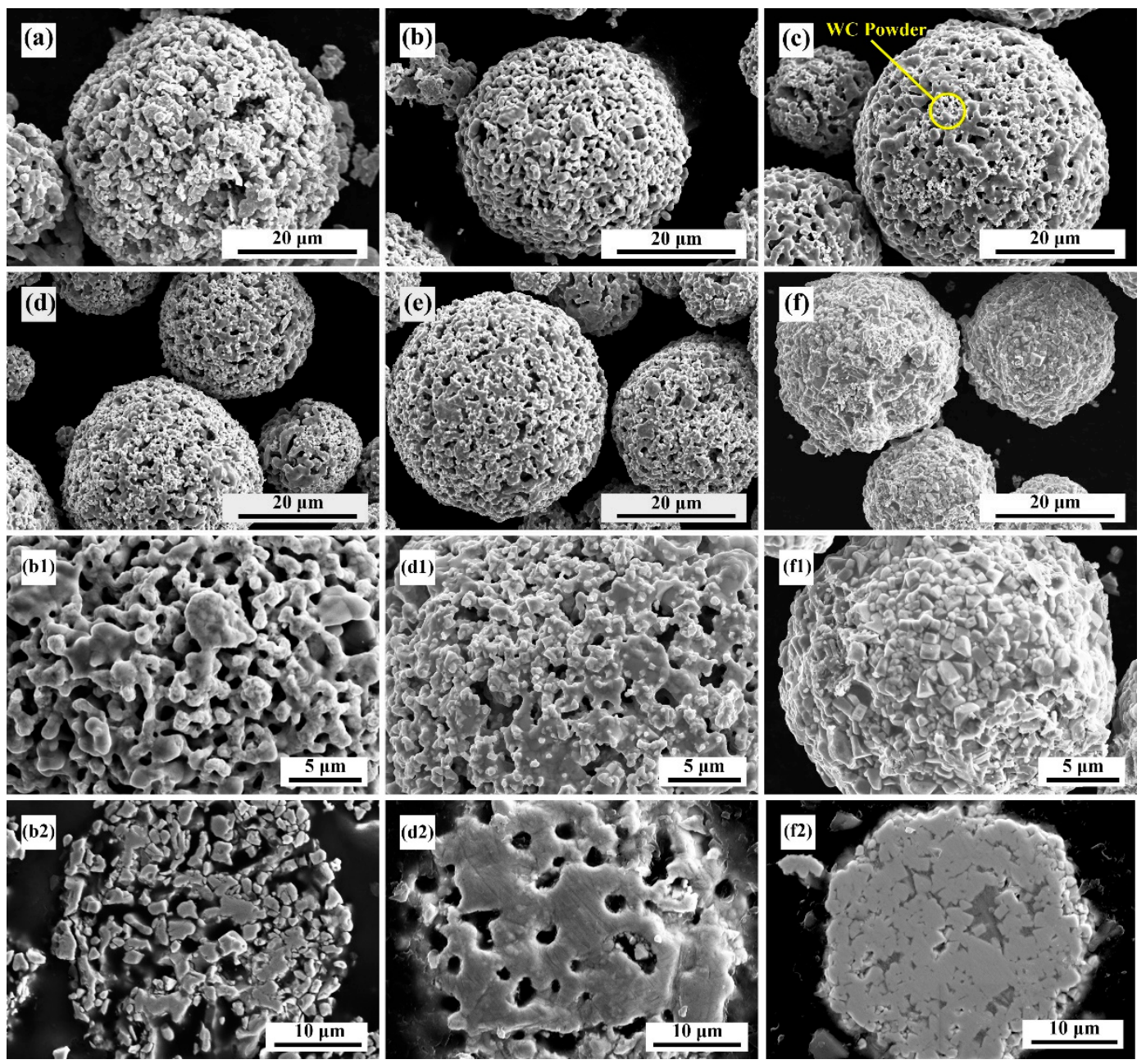

Figure 3. SEM micrographs of cross-sectional microstructures of composite powders: (a) \#1; (b) \#2; (c) \#3; (d) \#4; (e) \#5; (f) \#6. High-magnification micrographs of composite powders: (b1) \#2; (d1) \#4; (f1) \#6. Micrographs of cross-sectional microstructures of composite powders: (b2) \#2; (d2) \#4; (f2) \#6.

This outcome is more obvious in Figure 3b1. Owing to the small amount of the bonded phase, more pores are visible on the surface of the composite powder, and the particles are fine and broken. The surface morphologies of samples \#3, \#4, and \#5 are similar. Co reacts with $\mathrm{Mo}-\mathrm{B}_{4} \mathrm{C}$ to produce a ternary boride ceramic phase binder. Additionally, some of the Co is retained as the bonding phase, with fewer surface defects. Simultaneously, the raw material powder is well bonded, and the particle sizes are evenly mixed to form a composite powder. Furthermore, samples \#3-\#6 show WC powder particles of smaller size adhered to the composite powder. Sample \#6 shows the typical WC-12Co granulation morphology: the Co bonding phase is fully enveloped by the smaller WC hard phase particles, with no pore defects visible on the surface. The cross-sectional morphologies of samples \#2, $\# 4$, and \#6 are shown in Figure $3 \mathrm{~b} 2-\mathrm{f} 2$. The internal binding of \#2 composite powder particles with excess $\mathrm{Mo}-\mathrm{B}_{4} \mathrm{C}$ was poor, and no metallurgical binding formed between the particles. However, for \#4 composite powder the intergranular combination was good, and the powder combination was good. Although some pores remain visible, no obvious interface is evident. The interior of the \#6 powder composite was a combination of WC and Co. WC and Co show good macroscopic combination, with few defects. The addition of $\mathrm{Mo}-\mathrm{B}_{4} \mathrm{C}$ and $\mathrm{Co}$ resulted in an in-situ reaction, and the ternary boride thus formed intersected with WC. The binding state of each raw material powder in the composite powder further affects the microstructure and mechanical properties of the prepared coating. 


\subsection{Effect of $\mathrm{Mo}-\mathrm{B}_{4} \mathrm{C}$ on the Morphology and Densification Process of the Coating}

The composite coatings with different powder composition ratios were prepared using supersonic flame spraying. Typical \#2, \#4, and \#6 coating tissues were selected for comparison, respectively, representing the excess addition of $\mathrm{Mo}-\mathrm{B}_{4} \mathrm{C}$ coating ( $\left.\# 2\right)$, suitable addition of $\mathrm{Mo}-\mathrm{B}_{4} \mathrm{C}$ coating ( $\left.\# 4\right)$, and absence of Mo- $\mathrm{B}_{4} \mathrm{C}$ (\#6). The cross-sectional microstructures of the coatings are shown in Figure $4 \mathrm{~b} 3-\mathrm{f} 3$, showing that coatings with different ratios combine well with the matrix layer. The microstructure of coating \#2 is shown in Figure $4 \mathrm{~b} 3$. Owing to the lack of a cohesive Co phase and the excessive addition of $\mathrm{Mo}-\mathrm{B}_{4} \mathrm{C}$, a large quantity of $\mathrm{MoB}$ or $\mathrm{MoB}_{2}$ was generated, resulting in numerous pore defects in the coating microstructure. Large pores remained in the coating, with diameters around $10 \mu \mathrm{m}$. Particles inside the pores failed to combine with the matrix, and microcracks were generated around them. Owing to the existence of pores, some particles were not fully bonded, and micro-cracks seriously diminished the coating strength and mechanical properties.
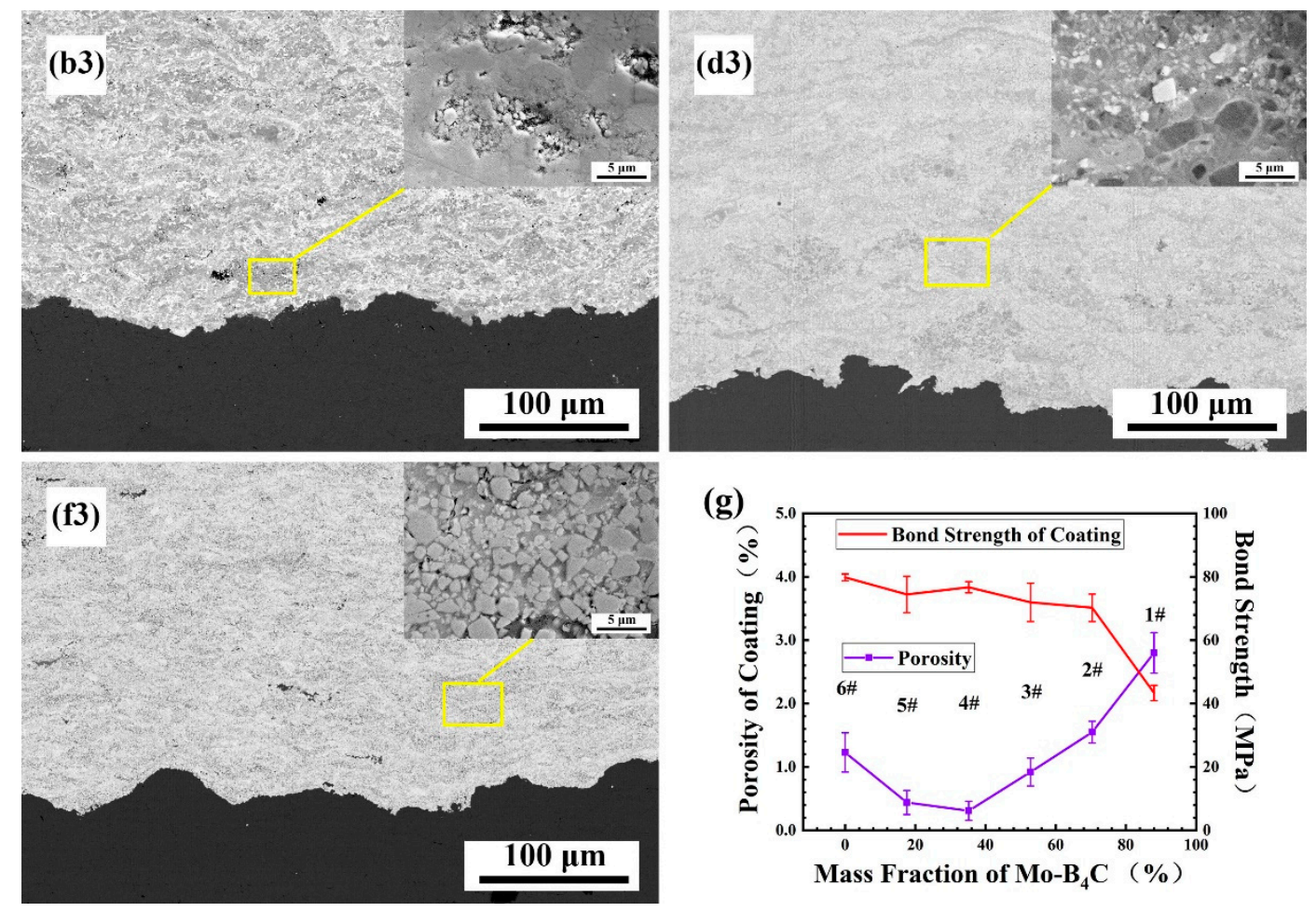

Figure 4. Cross-sectional microstructure of coating with different $\mathrm{Mo}-\mathrm{B}_{4} \mathrm{C}$ additions: (b3) \#2; (d3) \#4; (f3) \#6. (g) Porosities and bond strengths of the coatings.

The structure of coating \#4 is shown in Figure $4 \mathrm{~d} 3$. The coating structure is uniform, and no pores can be observed. The enlarged diagram shows that the numerous hard phases generated are evenly distributed in the matrix. The microstructure of coating \#6 is shown in Figure $4 \mathrm{f} 3$. This coating, lacking Mo- $\mathrm{B}_{4} \mathrm{C}$, also shows certain pore defects. The enlarged structure shows that $\mathrm{WC}$ particles are evenly distributed in the matrix of the Co bonding phase; however, the combination of Co and WC is not good. Thus, tiny pores exist at the interfaces between the WC particles and Co.

The coating's microstructure and defects both affect the bonding strength of the coating. Therefore, we measured the porosity of coatings with different compositional ratios and calculated their bonding strengths, as shown in Figure $4 \mathrm{~g}$. With increasing addition of Mo- $\mathrm{B}_{4} \mathrm{C}$, the porosity of the coating first decreased and then increased, with the \#4 coating exhibiting a porosity minimum. In coatings $\# 6$, \#5, and \#4, the addition of $M o-B_{4} C$ reacted with Co to produce ternary boride: $\mathrm{CoMoB}$ and $\mathrm{CoMo}_{2} \mathrm{~B}_{2}$. This in-situ reaction resulted in better interfacial bonding between Co and reaction products. Simultaneously, Mo and W showed better wettability and mutual diffusion ability, resulting in a better 
interface between Mo and $\mathrm{W}$. Therefore, $\mathrm{Mo}$ and $\mathrm{B}_{4} \mathrm{C}$ can act as the media to form a perfect interface between Co and WC.

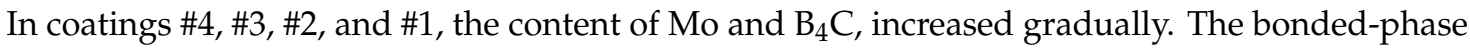
Co was largely consumed, making it difficult for the excess ceramic phase in the matrix to be completely densified. In contrast, when $\mathrm{Mo}$ and $\mathrm{B}_{4} \mathrm{C}$ were in excess, $\mathrm{MoB}$ or $\mathrm{MoB}_{2}$ was generated. This binary boride was the same as WC, and the difficulty it showed in combining with the matrix resulted in further porosity increase. The porosity of a given coating affects its bonding strength. Among the coatings with $\mathrm{Mo}$ and $\mathrm{B}_{4} \mathrm{C}$, coating \#4 showed the highest bonding strength, owing to the reduction in defects. Compared with coating \#4, coating \#6 without Mo and $\mathrm{B}_{4} \mathrm{C}$ showed a slightly higher bond strength owing to the higher bond strength of metal Co compared with ternary boride as the bond phase. Even though the porosity was high, the numerous metal bond phases provided a higher bond strength.

\subsection{Microstructural Evolution of Coating}

To further analyze the changes in coating microstructure, bonding phase, and hard phase during supersonic flame spraying, TEM was used in combination with selective electron diffraction and EDS to analyze coating microstructures at different compositional ratios. Figure 5 a shows the clear field image of the microstructure of coating \#2. Because of the high temperature of supersonic flame spraying, the matrix is amorphous. The hard phase is evenly distributed in the matrix. The excess Mo and $\mathrm{B}_{4} \mathrm{C}$ in sample \#2 reveal WC and MoB particles in the coating wherein WC particles appear as irregular angular blocks, whereas MoB particles are spherical. Meanwhile, in the images of coating \#4 in Figure $5 b$, the coating matrix is also amorphous. The ternary borides $\mathrm{CoMoB}$ and $\mathrm{CoMo}_{2} \mathrm{~B}_{2}$ are uniformly distributed in the matrix.

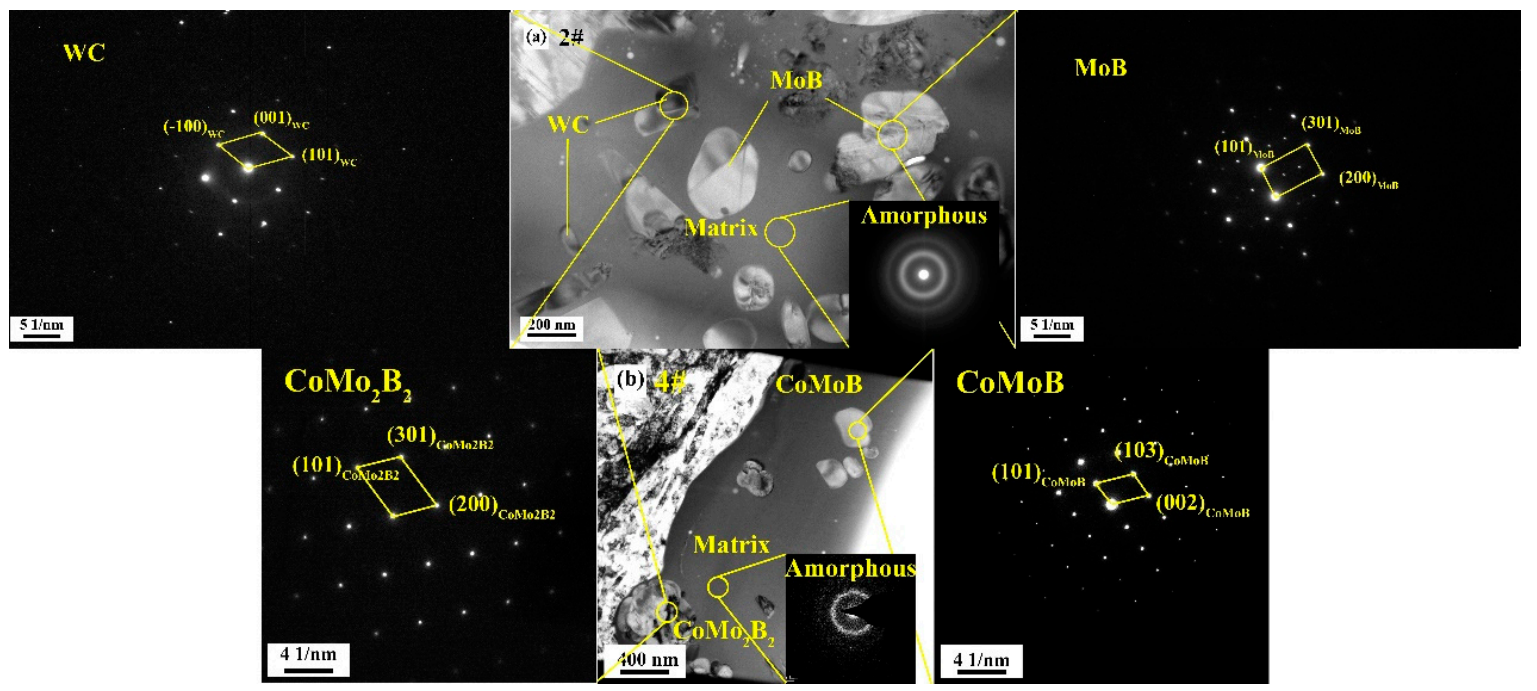

Figure 5. Transmission Electron Microscope (TEM)s and selected area electron diffraction diagrams of coatings: (a) \#2; (b) \#4.

The locations of W, Mo, and Co and the interface conditions were further analyzed in sample \#4, which showed the lowest porosity and the best bonding strength. Figure 6a shows a TEM image of the microstructure of coating \#4. The particle has internal and external structure, and its overall diameter is $34.28 \mathrm{~nm}$. The energy spectrum of the inner structure shows only W and C, indicating only WC molecules, whereas the outer structure contains W, Mo, and C. Figure $6 \mathrm{~b}$, showing the selected electron diffraction spot at the interface of the inner and outer layers of the particle, includes the diffraction spots of two phases, namely $\mathrm{WC}$ and $\mathrm{CoMo}_{2} \mathrm{~B}_{2}$, under the same belt axis. According to the energy spectrum data, the inner structure should be $\mathrm{WC}$, whereas the outer structure should be $\mathrm{CoMo}_{2} \mathrm{~B}_{2}$. Moreover, the two phases of $\mathrm{CoMo}_{2} \mathrm{~B}_{2}$ and WC show a certain crystallographic orientation relationship, 
indicating that $\mathrm{CoMo}_{2} \mathrm{~B}_{2}$ and $\mathrm{WC}$ have a good interface combination, ideally a perfect interface. Sun et al. [21], found that the in-situ reaction of $\mathrm{B}_{4} \mathrm{C}$ led to forming a continuous perfect interface. Compared with discontinuous interface, perfect interface can avoid crack initiation at the interface between hard particle and matrix. Therefore, the action of the bearing force of a hard particle will not form microcracks in this system, as the transmission of stress will not become discontinuous. Figure $6 \mathrm{c}$ is the high-angle annular dark-field (HAADF)-STEM mode mapping diagram, showing (1) an obvious mutual diffusion between the Mo in the particle exterior and $W$ in the particle interior, and the (2) perfect combination of $\mathrm{W}$ and $\mathrm{Co}$. This finding further demonstrates the continuity of the perfect interface. In sum, the ternary borides $\mathrm{CoMo}_{2} \mathrm{~B}_{2}$ and $\mathrm{CoMoB}$, formed with appropriate addition of Mo and $\mathrm{B}_{4} \mathrm{C}$ in sample \#4, can be used as the medium to form a perfect interface between WC and Co. In the presence of the boride ceramic bonding phase, the internal pores of the coating are reduced, and the particles are well combined with the matrix. The existence of a perfect interface further optimizes the mechanical properties of the coating. Simultaneously, ternary boride is used as the ceramic bonding phase instead of Co metal, reducing the number of defects in the coating. This defect reduction can effectively enhance the corrosion-resistance of the coating in high-temperature molten zinc aluminum.
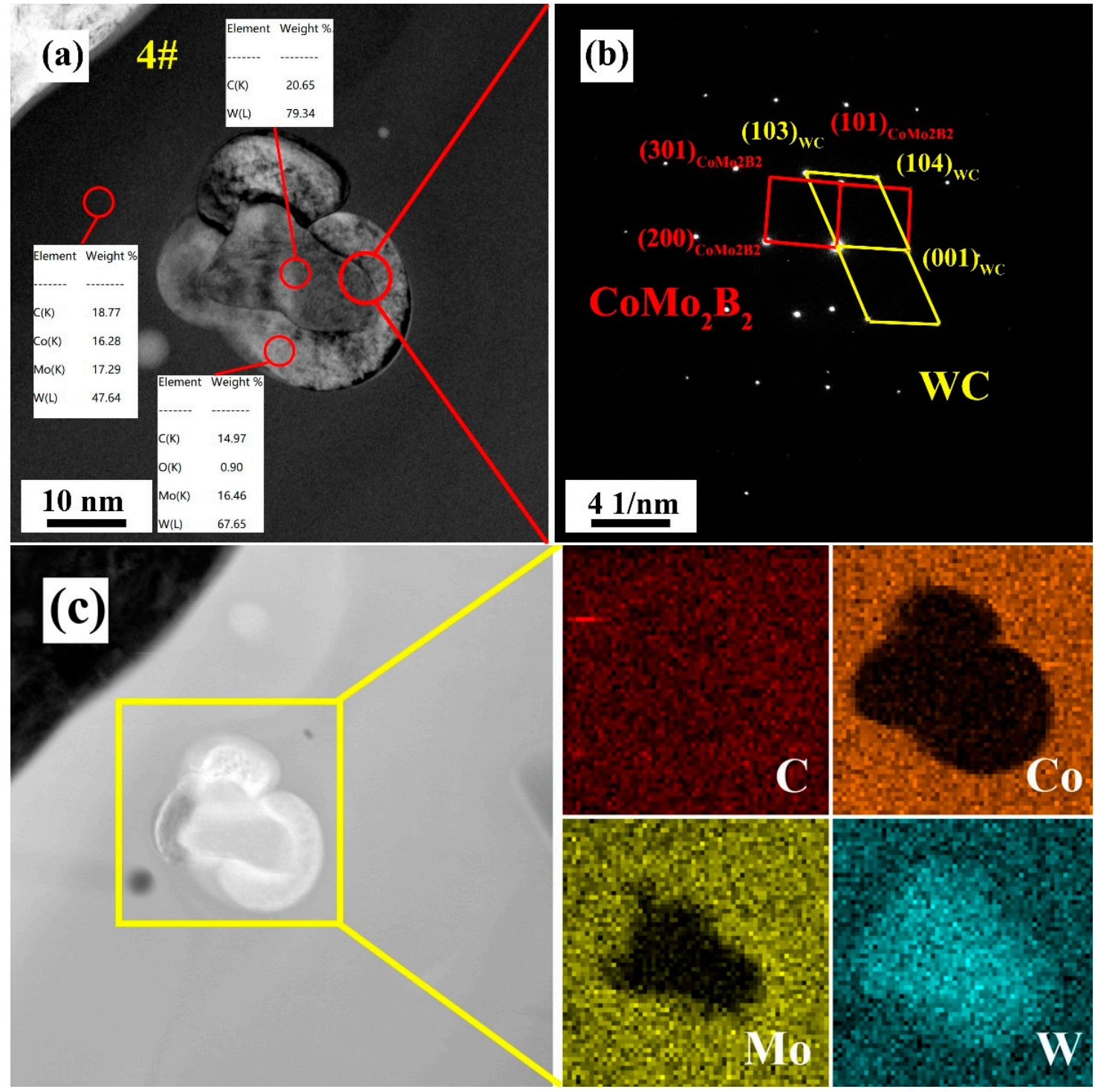

Figure 6. (a) Bright field image and EDS of \#4 coating; (b) selected area electron diffraction diagram of 4\# coating; (c) high-angle annular dark-field scanning transmission electron microscopy (HAADF-STEM) mapping of \#4 coating. 


\subsection{Mechanical Property Evolution of Coating by $\mathrm{Mo}-\mathrm{B}_{4} \mathrm{C}$ Addition}

Figure $7 \mathrm{a}$ shows the changes in nanoindentation hardness and Young's modulus with the compositional trend among coatings. As the amount of $\mathrm{Mo}+\mathrm{B}_{4} \mathrm{C}$ increased, the nanoindentation hardness tended to first increase and then decrease. This pattern can be explained as follows: the added $\mathrm{Mo}+\mathrm{B}_{4} \mathrm{C}$ reacted with $\mathrm{Co}$ to form a hard phase; hence, the nanohardness increased initially. However, when the added amount of $\mathrm{Mo}+\mathrm{B}_{4} \mathrm{C}$ exceeded $35.2 \mathrm{wt}$. \%, Mo $+\mathrm{B}_{4} \mathrm{C}$ was in excess, generating binary borides instead of ternary borides. Although the hardness of MoB is higher than that of $\mathrm{CoMo}_{2} \mathrm{~B}_{2}$, the appearance of $\mathrm{MoB}$ was accompanied by the formation of pore defects and a poor combination between $\mathrm{MoB}$ and matrix. These behaviors resulted in a decline in nanohardness as the amount of $\mathrm{Mo}+\mathrm{B}_{4} \mathrm{C}$ continued to increase. A similar pattern was observed in Young's modulus. The only difference was that the Young's modulus of the coating without $\mathrm{Mo}+\mathrm{B}_{4} \mathrm{C}$ was slightly higher than that of the optimal additive coating \#4. This disparity can be explained as follows: the coating structure without $\mathrm{Mo}+\mathrm{B}_{4} \mathrm{C}$ was mainly Co matrix combined with WC hard phase, and numerous Co metal bonding phases provided a high Young's modulus. Figure $7 \mathrm{~b}$ shows the change in fracture toughness of the coating with increasing addition of $\mathrm{Mo}+\mathrm{B}_{4} \mathrm{C}$; the trend in fracture toughness is similar to that of Young's modulus. In contrast with sample \#6, which lacked Mo $+\mathrm{B}_{4} \mathrm{C}$, the other samples' reactions consumed part of the Co metal bonding phase. With this change in the ceramic phase, the fracture toughness of the coating was reduced to a certain extent. As the addition of Mo + $\mathrm{B}_{4} \mathrm{C}$ continued to increase to $35.2 \mathrm{wt}$. \%, numerous ternary borides were generated to replace $\mathrm{Co}$ as the ceramic bonding phase, and the interfacial bonding was better than that of $\mathrm{Co}-\mathrm{WC}$. This phenomenon promoted the coating's increase in fracture toughness. As the addition of $\mathrm{Mo}+\mathrm{B}_{4} \mathrm{C}$ continued to increase, the formation of a large number of defects and the formation of binary borides such as $\mathrm{MoB}$ lost the advantage of good interfacial bonding between ternary borides and $\mathrm{Co}-\mathrm{WC}$, which resulted in the coating's decrease in fracture toughness.

(a)

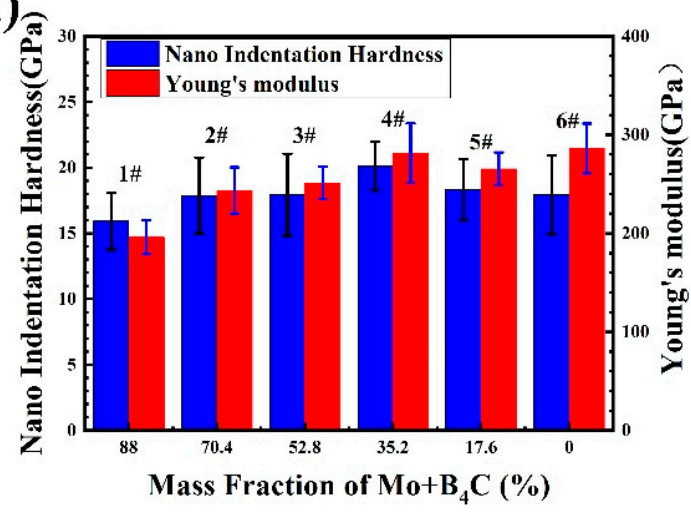

(b)

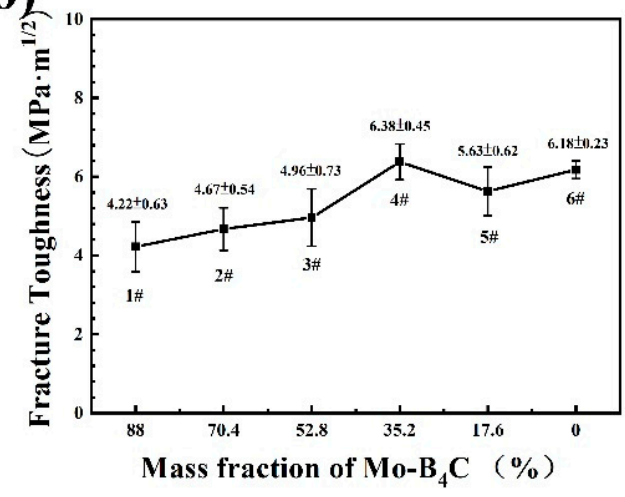

Figure 7. (a) Nanoindentation hardnesses and Young's moduli of coatings; (b) fracture toughnesses of coatings.

\subsection{Corrosion Resistance Property Evolution of Coating by $\mathrm{Mo}-\mathrm{B}_{4} \mathrm{C}$ Addition}

Figure 8 shows the cross-section structure of the composite coating with different $\mathrm{Mo}-\mathrm{B}_{4} \mathrm{C}$ addition after $72 \mathrm{~h}$ and $630^{\circ} \mathrm{C}$ molten zinc aluminum corrosion. It can be seen that most of the coating and $\mathrm{NiCrAlY}$ intermediate layer are corroded, and the surface structure is zinc aluminum alloy, as shown in Figure $8 \mathrm{a} 1 \#$ coating sample. This is due to the poor bonding ability of the structure and the existence of a large number of pore defects in the $1 \#$ coating, which makes it easier for the molten zinc aluminum to etch the coating and make the coating peel off. Figure $8 b-e$ shows the difference of the thickness of the corrosion layer of the composite coating with different Mo- $\mathrm{B}_{4} \mathrm{C}$ addition. After $72 \mathrm{~h}$ of molten zinc aluminum corrosion testing, the corrosion layer of $4 \#$ coating is the thinnest, with an average thickness of $21.37 \mu \mathrm{m}$, showing the best corrosion resistance performance of molten zinc aluminum. On the one hand, the better interface combination makes it difficult for the molten zinc aluminum corrosion to 
diffuse inward through defects; on the other hand, the good corrosion resistance of the ternary boride also makes the corrosion resistance of the $4 \#$ coating greatly improved. However, for the $6 \# 12 \mathrm{Co}-\mathrm{WC}$ coating without $\mathrm{Mo}-\mathrm{B}_{4} \mathrm{C}$ addition, the whole coating is corroded and there are a lot of pores in the coating due to the reaction of $\mathrm{Co}$ as a metal bonding phase with molten zinc aluminum.
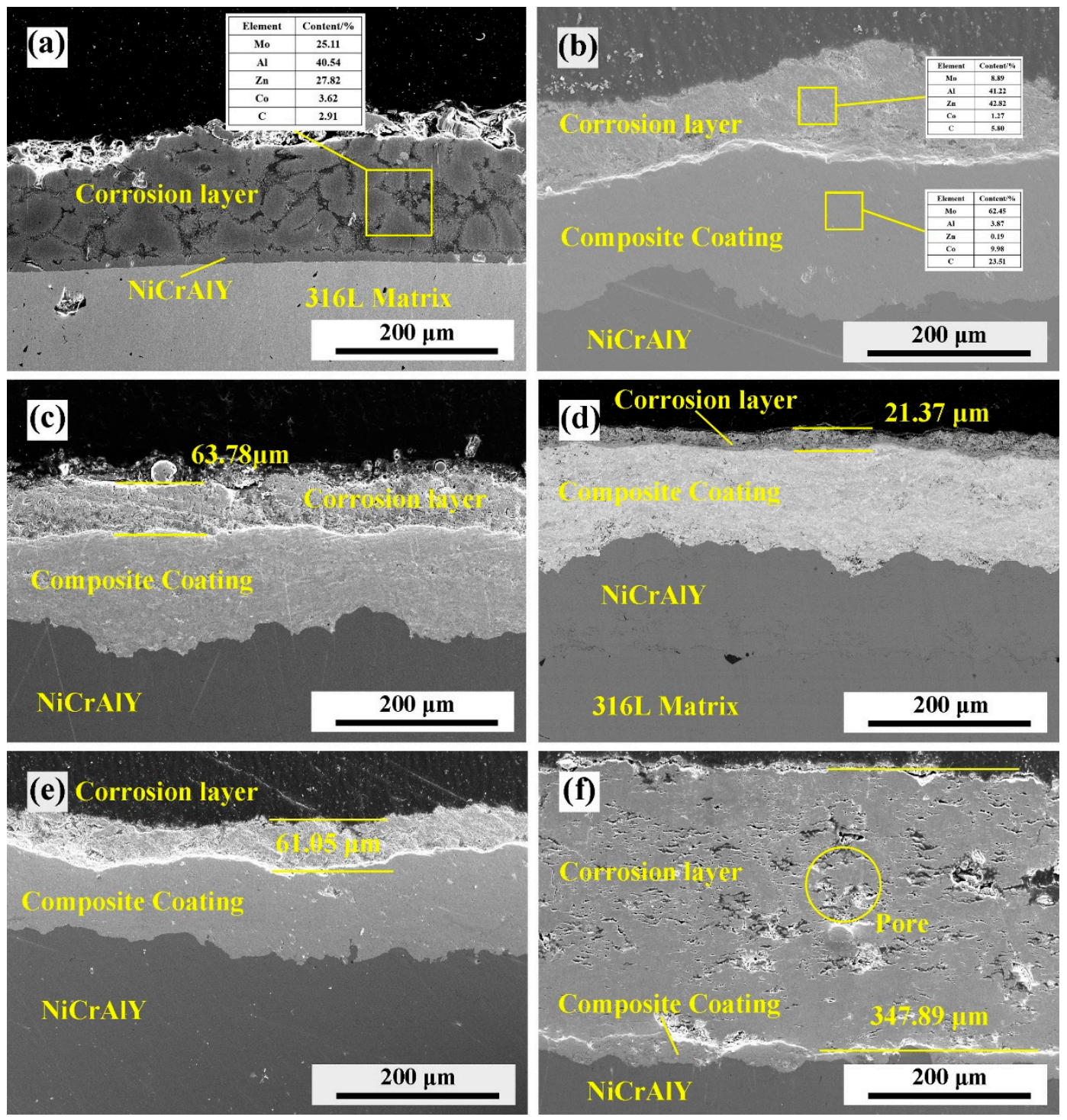

Figure 8. SEM micrographs of cross-sectional microstructures of composite coating after $72 \mathrm{~h}$ and $630{ }^{\circ} \mathrm{C}$ molten zinc aluminum corrosion: $(\mathbf{a}) \# 1 ;(\mathbf{b}) \# 2 ;$ (c) \#3; (d) \#4; (e) \#5; (f) \#6.

In conclusion, the microstructure of WC-12Co changed with the addition of $\mathrm{Mo}+\mathrm{B}_{4} \mathrm{C}$ and showed a trend with increasing addition of $\mathrm{Mo}+\mathrm{B}_{4} \mathrm{C}$. The microstructural change caused corresponding changes in the mechanical properties and corrosion resistance property of the coating. These changes can be assigned to two processes: (1) Mo $+\mathrm{B}_{4} \mathrm{C}$ was added to WC-12Co to form ternary borides $\mathrm{CoMo}_{2} \mathrm{~B}_{2}$ and $\mathrm{CoMoB}$. Because $\mathrm{Mo}$ and $\mathrm{W}$ showed good mutual diffusion and because Co could participate in the reaction to form ternary borides in situ, ternary borides $\mathrm{CoMo}_{2} \mathrm{~B}_{2}$ and $\mathrm{CoMoB}$ showed perfect interfaces with WC and Co. This interfacial perfection increased the density, hardness, and fracture toughness of the coating, which all reached maximum values at 35.2 wt. $\% \mathrm{Mo}+\mathrm{B}_{4} \mathrm{C}$. In this process, the addition of $\mathrm{Mo}+\mathrm{B}_{4} \mathrm{C}$ served as the medium for a perfect interface between WC and Co. Simultaneously, the consumption of a large amount of $\mathrm{Co}$ and the generation of a ceramic bonding phase provided conditions that improved the corrosion resistance of the coating to molten zinc 
aluminum. (2) With the excess addition of $\mathrm{Mo}+\mathrm{B}_{4} \mathrm{C}$, the excessive consumption of the Co metal bonding phase reduced the coating density. Simultaneously, the excess $\mathrm{Mo}+\mathrm{B}_{4} \mathrm{C}$ resulted in the generation of binary boride $\mathrm{MoB}$, which contributed to the formation of numerous defects and imperfect interfaces. These interfaces and defects contributed to the deterioration of mechanical properties. Therefore, the optimal addition amount of $\mathrm{Mo}+\mathrm{B}_{4} \mathrm{C}$ is $35.2 \mathrm{wt}$. \%: $31.5 \mathrm{wt}$. \% Mo, $3.7 \mathrm{wt}$. $\% \mathrm{~B}_{4} \mathrm{C}$. At this composition, the mechanical properties were optimal: the minimum porosity was $0.31 \pm 0.15 \%$, the coating bonding strength reached $77.81 \pm 1.77 \mathrm{MPa}$, the nanoindentation hardness was $20.12 \pm 1.85 \mathrm{GPa}$, the Young's modulus was $281.52 \pm 30.22 \mathrm{GPa}$, and the fracture toughness was $6.38 \pm 0.45 \mathrm{MPa} \cdot \mathrm{m}^{1 / 2}$. The mechanical properties of the in-situ ternary boride composite coating are comparable to that of WC Co, and the ternary boride can effectively prevent the coating from being corroded by high temperature molten zinc. The corrosion-resistant $\mathrm{wc}-\mathrm{wb}-\mathrm{w} 2 \mathrm{~b}$ ceramics prepared by Sugiyama et al. [18] have an initial fracture toughness of less than $5.8 \mathrm{MPa} \cdot \mathrm{m}^{1 / 2}$ and a Young's modulus of up to $700 \mathrm{GPa}$. In contrast, the ternary boride composite coating has the advantages of mechanical properties, and the difference of Young's modulus between the ternary boride composite coating and the matrix is smaller. Compared with ceramic coating, the composite coating prepared has better toughness and adaptability.

\section{Conclusions}

1. Composite powders of different proportions of $\mathrm{Mo}-\mathrm{B}_{4} \mathrm{C}, \mathrm{WC}$, and $\mathrm{Co}$ were prepared by mixing, granulation, and heat treatment. When a small amount of $M o-B_{4} C$ was added, it reacted with $\mathrm{Co}$ to produce ternary borides $\mathrm{CoMo}_{2} \mathrm{~B}_{2}$ and $\mathrm{CoMoB}$. When Mo- $\mathrm{B}_{4} \mathrm{C}$ was added to excess, Mo and $\mathrm{B}_{4} \mathrm{C}$ further reacted to generate $\mathrm{MoB}$ and $\mathrm{MoB}_{2}$.

2. Boride ceramics were formed in situ to replace part of the Co bonding phase to improve corrosion resistance. When the amount of $\mathrm{Mo}-\mathrm{B}_{4} \mathrm{C}$ added was $35.2 \%$, some pores were present in the composite powder, but the combination between components was good. When Mo- $\mathrm{B}_{4} \mathrm{C}$ was added to excess, then numerous pores were visible in the composite powder, and the combination of particles was poor.

3. When the amount of Mo- $\mathrm{B}_{4} \mathrm{C}$ was $35.2 \%$, the mechanical properties of the prepared coating reached optimal values: minimum porosity of $0.31 \pm 0.15 \%$, bonding strength of $77.81 \pm 1.77 \mathrm{Mpa}$, nanoindentation hardness of $20.12 \pm 1.85 \mathrm{GPa}$, Young's modulus of $281.52 \pm 30.22 \mathrm{GPa}$, and fracture toughness of $6.38 \pm 0.45 \mathrm{MPa} \cdot \mathrm{m}^{1 / 2}$.

4. The strengthening mechanism of $\mathrm{Mo}-\mathrm{B}_{4} \mathrm{C}$ in WC-Co composite coatings was as follows: the addition of $\mathrm{Mo}-\mathrm{B}_{4} \mathrm{C}$ reacted with $\mathrm{Co}$ to form ternary borides $\mathrm{CoMo}_{2} \mathrm{~B}_{2}$ and $\mathrm{CoMoB}$. Owing to the in-situ reaction, a perfect interface formed between $\mathrm{Co}$ and ternary boride. Simultaneously, ternary boride also formed a perfect interface with Mo and WC of a particular crystallographic orientation. Therefore, the addition of $\mathrm{Mo}-\mathrm{B}_{4} \mathrm{C}$ improved the interface with $\mathrm{WC}-\mathrm{Co}$, forming a dense microstructure. This change improved the mechanical properties and corrosion resistance property of the coating.

Author Contributions: Conceptualization, Y.Y. and C.J.; methodology, J.B.; validation, J.B., B.L. and C.W.; formal analysis, J.B.; investigation, B.L.; resources, J.B.; data curation, B.L.; writing-original draft preparation, J.B.; writing-review and editing, B.L., C.J. and Y.Y.; project administration, Y.Y.; funding acquisition, Y.Y. All authors have read and agreed to the published version of the manuscript.

Funding: This research is financially supported by National Key R\&D Program of China (No: 2017YFB0306100).

Conflicts of Interest: The authors declare no conflict of interest.

\section{References}

1. Tsipas, D.N.; Triantafyllidis, G.K.; Kiplagat, J.K.; Psillaki, P. Degradation behavior of boronized carbon and high alloy steels in molten aluminum and zinc. Mater. Lett. 1998, 37, 128-131. [CrossRef]

2. Fang, X.; Wang, Y.; Zhang, Y.; Feng, S.; Du, J.; Liu, D.; Ouyang, T.; Suo, J.; Cai, S. Improving the corrosion resistance of Fe-21Cr-9Mn alloy in liquid zinc by heat treatment. Corros. Sci. 2016, 111, 362-369. [CrossRef] 
3. Ren, X.J.; Mei, X.Z.; She, J.; Jiang-hong, M.A. Materials Resistance to Liquid Zinc Corrosion on Surface of Sink Roll. J. Iron Steel Res. Int. 2007, 14, 130-136. [CrossRef]

4. Wang, W.J.; Lin, J.P.; Wang, Y.L.; Chen, G.L. The corrosion of intermetallic alloys in liquid zinc. J. Alloy. Compd. 2007, 428, 243. [CrossRef]

5. Cao, X.M.; Yi, L.; Run, W. Mechanism of liquid zinc corrosion on metals. Int. J. Miner. Metall. Mater. 1997, 3, 22-26.

6. Armstrong, R.W. The Hardness and Strength Properties of WC-Co Composites. Materials 2011, 4, 1287-1308. [CrossRef] [PubMed]

7. Wang, Z.H.; Jia, J.H.; Wang, B.X.; Wang, Y. Two-Step Spark Plasma Sintering Process of Ultrafine Grained WC-12Co-0.2VC Cemented Carbide. Materials 2019, 12, 2443. [CrossRef] [PubMed]

8. Konyashin, I.; Zaitsev, A.; Meledin, A.; Mayer, J.; Loginov, P.; Levashov, E.; Ries, B. Interfaces between Model Co-W-C Alloys with Various Carbon Contents and Tungsten Carbide. Materials 2018, 11, 404. [CrossRef] [PubMed]

9. Bjorndal, M.; Bardal, E.; Rogne, T.; Eggen, T.G. Erosion and corrosion properties of WC coatings and duplex stainless steel in sand-containing synthetic sea water. Wear 1995, 186-187, 508-514. [CrossRef]

10. Souza, V.A.; Neville, A. Corrosion and erosion damage mechanisms during erosion-corrosion of $\mathrm{WC}-\mathrm{Co}-\mathrm{Cr}$ cermet coatings. Wear 2008, 255, 146-156. [CrossRef]

11. Wang, W.J.; Lin, J.P.; Wang, Y.L. Corrosion of 316 stainless steel/WC-Co coating in liquid zinc. J. Aeronaut. Mater. 2006, 26, 56-60.

12. Ying, K.L.; Dian, R.Y.; Dong, L.Z. Study on the Material of Inside Heating Casing for Galvanizing by Dipping. Shandong Ceram. 2006, 29, 16-19.

13. Shimizu, J.; Ohmura, E.; Kobayashi, Y.; Kiyoshima, S.; Eda, H. Molecular Dynamics Simulation of Flattening Process of a High-Temperature, High-Speed Droplet-Influence of Impact Parameters. J. Therm. Spray Technol. 2007, 16, 722-728. [CrossRef]

14. Lv, H.; Nie, P.; Yan, Y.; Sun, B. Characterization and adhesion strength study of detonation-sprayed $\mathrm{MoB}-\mathrm{CoCr}$ alloy coatings on 2Cr13 stainless steel substrate. J. Coat. Technol. Res. 2010, 7, 801-807. [CrossRef]

15. Khan, F.F.; Bae, G.; Kang, K.; Na, H.; Kim, J.; Jeong, T.; Lee, C. Evaluation of Die-Soldering and Erosion Resistance of High Velocity Oxy-Fuel Sprayed MoB-Based Cermet Coatings. J. Therm. Spray Technol. 2011, 20, 1022-1034. [CrossRef]

16. Chen, X.; Zhang, R. Corrosion Behavior of Low-Pressure Plasma Sprayed MoB/CoCr Coatings Exposed to Molten Al-12.07wt.\%Si Alloy. Procedia Eng. 2012, 27, 1766-1773. [CrossRef]

17. Zhang, J.F.; Deng, C.M.; Song, J.B.; Deng, C.; Liu, M.; Zhou, K. MoB-CoCr as alternatives to WC-12Co for stainless steel protective coating and its corrosion behavior in molten zinc. Surf. Coat. Technol. 2013, 235, 811-818. [CrossRef]

18. Sugiyama, S.; Taimatsu, H. Mechanical properties of WC-WB-W2B composites prepared by reaction sintering of B4C-W-WC powders. J. Eur. Ceram. Soc. 2004, 24, 871-876. [CrossRef]

19. Wang, H.; Hou, C.; Liu, X.; Liu, X.; Song, X. Phase evolution in synthesis of nanocrystalline WC- $\eta$ composite powder by solid-state in situ reactions. Int. J. Refract. Met. Hard Mater. 2018, 71, 21-27. [CrossRef]

20. Song, H.P. Preparation and Study of a New Ternary Borides Based Ceramic Coating. Ph.D. Thesis, Shanghai Jiao Tong University, Shanghai, China, 2010.

21. Sun, Y.H.; Wu, J.H.; He, L.K.; Liu, B.; Zhang, C.; Meng, Q.; Zhang, X. Influence of $\mathrm{B}_{4} \mathrm{C}$ coating on graphitization for diamond/WC-Fe-Ni composite. Int. J. Refract. Met. Hard Mater. 2020, 88, 105208. [CrossRef]

(C) 2020 by the authors. Licensee MDPI, Basel, Switzerland. This article is an open access article distributed under the terms and conditions of the Creative Commons Attribution (CC BY) license (http://creativecommons.org/licenses/by/4.0/). 